\title{
Prevalence of Asymptomatic Bacteriuria among Pregnant Women Attending Antenatal Clinics in Ovia North East Local Government Area, Edo State, Nigeria
}

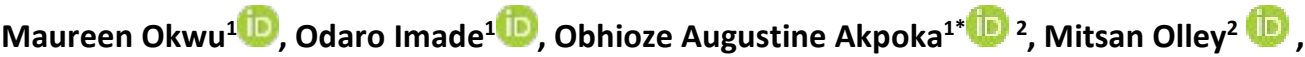 \\ Blessing Ashi-ingwu ${ }^{1}$
}

1. Department of Biological Sciences, College of Natural and Applied Sciences, Igbinedion University, Okada, Edo State, Nigeria

2. Department of Medical Laboratory Science, College of Health Sciences, Igbinedion University, Okada, Edo State, Nigeria

\section{ABSTRACT}

Background and Aim: Asymptomatic bacteriuria is bacteria in the properly collected urine of a patient, leading to a urinary tract infection with no symptoms. Asymptomatic bacteriuria is a common complication in clinical practice with an increasing prevalence due to increase of age. The present study investigated the prevalence of asymptomatic bacteriuria among pregnant women receiving antenatal care in Ovia North East Local Government Area, Edo State, Nigeria.

Materials and Methods: A total of 201 urine samples were collected randomly from pregnant women at Igbinedion University Teaching Hospital, Okha Maternity and Usen General Hospital in in Ovia North East Local Government Area. The bacteria isolation was carried out using the pour plate technique. The bacteria identification was conducted by gram staining and biochemical tests and the antibiotic susceptibility pattern of the bacterial isolates was determined by Kirby-Bauer disc diffusion technique.

Results: Eighty-one of the subjects had significant bacteriuria, with a prevalence of $40.3 \%$. The bacteria isolated in the samples were Streptococcus, Proteus, Klebsiella and Micrococcus species as well as Staphylococcus epidermidis, Escherichia coli and Staphylococcus aureus. Streptococcus spp. occurred more frequently (42.0\%) while S. aureus had the lowest frequency of occurrence $(2.5 \%)$ in the samples. The infection was most prevalent among women aged between 28 and 37 years $(74.5 \%)$. Pregnant women in their third trimester in this study had the highest prevalence of asymptomatic bacteriuria $(55.2 \%)$. Ciprofloxacin was found to be the most effective antibiotic against the urinary isolates.

Conclusion: Pregnancy promotes the progression from symptomatic to asymptomatic bacteriuria with its consequences such as pyelonephritis and increased fetal mortality. Therefore, routine culture test should be carried out for all antenatal women to detect asymptomatic bacteriuria and all positive cases should be treated with appropriate antibiotic therapy to prevent any obstetric complications which are associated with pregnancy.

Keywords: Asymptomatic Bacteriuria, Gentamycin, Pregnancy, Streptococcus spp

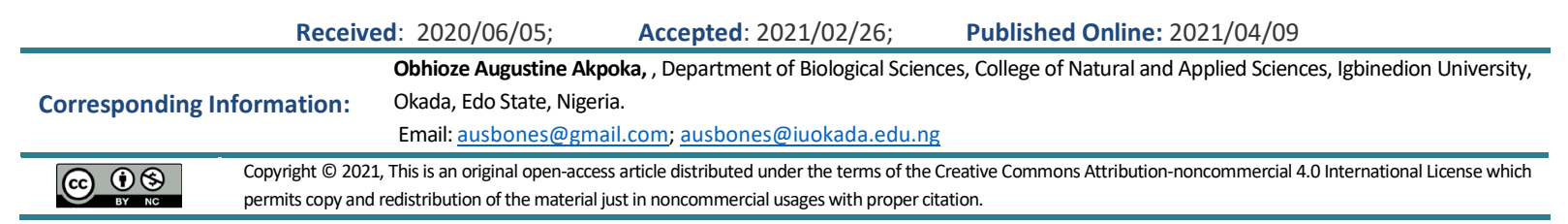

Use your device to scan and read the article online

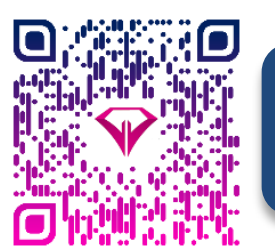

Okwu M, Imade O, Akpoka O A, Olley M, Ashi-ingwu B. Prevalence of Asymptomatic Bacteriuria among Pregnant Women Attending Antenatal Clinics in Ovia North East Local Government Area, Edo State, Nigeria. Iran J Med Microbiol. 2021; 15 (2) :227-231

\section{Download citation: BibTeX | RIS | EndNote | Medlars | ProCite | Reference Manager | RefWorks}
Send citation to:
8.
Mendeley
(2) Zotero
(H) RefWorks 


\section{Introduction}

Asymptomatic bacteriuria (ASB) or asymptomatic urinary infection is the isolation of bacteria, with bacterial counts of $\geq 10^{5} \mathrm{cfu} / \mathrm{mL}$, from appropriately voided and collected urine specimens from an individual with no acute signs and symptoms of urinary tract infections $(1,2,3)$. Bacteria are typically introduced into the urinary tract during sexual intercourse or when wiping after a bowel movement. The common etiology of ASB is usually coliform bacteria with Escherichia coli been as high as $75-80$ $\%$ (4). Klebsiella pneumoniae, Proteus spp., Staphylococci spp., Enterococci and group B Streptococci can also establish colonization. Pregnant women and patients who undergo traumatic urologic interventions with mucosal bleeding should be screened and treated for ASB. The apparent reduction in the immunity of pregnant women appears to encourage the growth of microorganisms including bacteria $(5,6)$. Pregnant women identified with ASB have 20 to 30 folds increased risk of developing asymptomatic urinary tract infection (UTI), acute cystitis and pyelonephritis, compared with those without bacteriuria. They are also more likely to experience premature delivery with infants with low birth weight (7). The adverse consequences of untreated ASB can be prevented by early detection in pregnancy and antimicrobial treatment. Early detection and treatment of ASB has been reported to prevent up to $80 \%$ cases of pyelonephritis. Prospective comparative clinical trials have consistently reported that antimicrobial treatment of ASB identified and treated in early pregnancy can decrease the risk of subsequent pyelonephritis later in pregnancy from $20-30 \%$ to $1-4 \%$ with improved fetal outcomes (7). ASB is not harmful to all other adult populations (7).

There is strong evidence not to screen for bacteriuria in premenopausal, non-pregnant women, diabetic women, elderly institutionalized men and women and patients with long- or short-term indwelling urethral catheters. During the past 50 years, the paradigm for ASB has shifted from being a harmful clinical finding requiring no management in most non-pregnant subjects and now, potentially, to be beneficial for some patients. Risk factors identified with ASB include sickle-cell disease, diabetes, immunosuppressive disorders, urinary tract obstructions (from stones), loss of bladder control (due to neuromuscular diseases) and need for chronic instrumentation of the bladder. ASB is rare in healthy young men. The prevalence in men increases substantially after the age of 60 years presumably because of obstructive uropathy and voiding dysfunction associated with prostatic hypertrophy (7). For healthy women, the prevalence increases with advancing age. Prevalence among young women is strongly associated with sexual activity and multiparity. Several studies have shown different prevalence rates of ASB in pregnancy with quoted values ranging from $3-10 \%$ in most developed countries. In most Asian countries and sub-Saharan Africa, prevalence rates ranging from $5.6-26 \%$ are reported. In Nigeria, studies have been conducted in different parts of the southeast region with the incidence of $A B S$ found to be $18.2-78.7 \%$; southwest $21 \%-47.5 \%$; south-south $58 \%-86.6 \%$ and northwest $8 \%(8,9,10)$.

The variation in the prevalence of ASB is explained by differences in the population characteristics and most importantly, differences in screening methodology and criteria for the diagnosis of ASB in these studies which in most cases are at variance with the accepted standard (11). In many hospitals in Nigeria, routine urine culture is not carried out on antenatal patients probably due to cost implications and time factor; instead, many clinicians opt for the dipstick method for assessing urine in pregnant women $(12,5)$. However, the dipstick method cannot quantify the extent of infection in such patients with ASB as well as provide antimicrobial therapy which is usually seen in the case of culture. The attention of health care providers is usually on the presence of glucose and protein in urine specimens much more than the possibility of asymptomatic infections (5). The value and cost-effectiveness of routine screening for ASB are controversial. However, it is agreed that it is worthwhile in populations with a high prevalence of ASB. Thus, this study was carried out to determine the prevalence of ASB in pregnant women attending antenatal clinics in Ovia North East Local Government Area in Edo State, Nigeria, as well as to isolate the causative organisms involved and their antibiotic susceptibility profiles.

\section{Materials and Methods}

\section{Study Population}

A total number of 201 healthy pregnant women who attended antenatal clinics at Igbinedion University Teaching Hospital, Okha Maternity and Usen General Hospital in Ovia North East Local Government of Edo State from April to June 2018 were assessed for asymptomatic bacteriuria. The study was approved by the Ethical Committee of the Igbinedion University teaching hospital (IUTH/CMAC/R4/789). Informed verbal informed consents were also obtained from each patient before sample collection. Sociodemographic data were obtained using personal interviews. The Criteria for exclusion was pregnant women with a history of fever, signs and symptoms of UTI and antibiotic usage. 


\section{Specimen Collection}

Clean-catch midstream urine samples of about 20 $\mathrm{mL}$ were collected in sterile universal containers with tight-fitting lids from pregnant women. All the samples were properly labelled and processed by using standard microbiological procedures.

\section{Bacterial Isolation and Enumeration}

Isolation of bacteria in the urine samples was carried out with the pour plate technique (13). Serial dilution of urine samples was made up to $10^{-4}$. One milliliter of each serially-diluted urine sample was mixed with 19 $\mathrm{mL}$ of sterile blood agar medium (nutrient agar was obtained from HiMedia Laboratories, India) in a sterile Petri dish and then allowed to solidify, followed by incubation of the Petri dish at $37^{\circ} \mathrm{C}$ for 24 hours. After incubation, bacterial colonies were counted with the colony counter and count was expressed as colonyforming units per milliliter (cfu/mL). Results were recorded as positive for asymptomatic bacteriuria if $\geq$ $10^{5} \mathrm{cfu} / \mathrm{mL}$ of urine sample were obtained. Cultures with a count of $10^{2}-10^{4} \mathrm{cfu} / \mathrm{mL}$ were recorded as suspected infections; cultures with less than $10^{2} \mathrm{cfu} / \mathrm{mL}$ were considered contaminated, while those with no growth of bacteria was recorded as negative (14).

\section{Identification of Bacterial Isolates}

The bacterial isolates obtained were identified by gram staining and biochemical tests (15).

\section{Antibiotic Susceptibility Testing}

The antibiotic susceptibility pattern of the bacterial isolates was determined by Kirby-Bauer disc diffusion technique according to the guidelines of the Clinical and Laboratory Standards Institute (CLSI) (16). Saline suspension of a pure bacterial culture adjusted to 0.5 McFarland standard was inoculated on sterile Mueller-Hinton agar Petri dish. Antibiotic discs were then placed on the agar surface and the Petri dish was incubated at $35^{\circ} \mathrm{C}$ for 18 hours. The antibiotics that

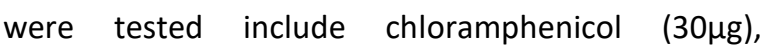

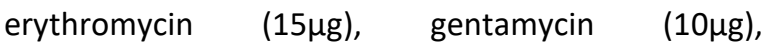
ciprofloxacin $(10 \mu \mathrm{g})$, cefuroxime $(20 \mu \mathrm{g})$, sparfloxacin $(10 \mu \mathrm{g})$, amoxicillin $(30 \mu \mathrm{g})$, cotrimoxazole $(10 \mu \mathrm{g})$ and ofloxacin $(10 \mu \mathrm{g})$. After incubation, bacterial inhibitory zone diameter around the antibiotics was interpreted as susceptible (sensitive), intermediate or resistant based on zone diameter breakpoints prescribed by CLSI. Escherichia coli ATCC 25922 and Staphylococcus aureus ATCC 25923 were used as control to detect potential errors

\section{Statistical Analysis}

Percentages and Fisher's exact tests using IBM SPSS Statistics version 22 (SPSS Inc., Chicago, III., USA) were applied for the analysis of data obtained in this study; P-value $>0.05$ was considered as statistically not significant.

\section{Results}

Of the 201 urine samples tested in this study, 3 $(1.5 \%)$ showed no bacterial growth; 13 (6.5\%) were contaminants, 104 (51.7\%) suspected infections while $81(40.3 \%)$ samples ( $\geq 10^{5} \mathrm{CFU}$ ) were positive for asymptomatic bacteriuria (Table 1 ).

Of the 81antenatal women with positive ASB, 46 $(29.9 \%)$ were in the age group of $18-27$ years while 35 (74.5\%) were 28-37years. There was a significant difference $(P=0.001)$ of ASB with respect to age (Table 2).

Table 3 shows the distribution of ASB by trimester among the antenatal women. There were 16 (26.2\%), $28(38.4 \%)$ and 37 (55.2\%) women with positive ASB for first, second and third trimesters respectively. There was no significant difference $(P=0.3)$ of ASB between the first and second trimesters. Also, no significant difference $(P=0.23)$ between the second and third trimesters. However, there was a significant difference $(P=0.03)$ between the first and third trimesters.

Table 4 shows the profile of bacteria isolated from the pregnant women with ASB. A total of 81 bacterial isolates were obtained. The most frequent isolate was Streptococcus while $S$. aureus least frequently occurred in the urine samples.

Table 5 shows the percentage of bacteria isolates susceptible to the nine (9) antibacterial agents. All the bacterial isolates were most susceptible to ciprofloxacin and least susceptible to cefuroxime.

Table 1. Prevalence of asymptomatic bacteriuria in 201 healthy pregnant women

\begin{tabular}{cccc}
\hline Bacteriuria & Colony forming units (No./mL) & No. of isolates & Percentage (\%) \\
\hline Positive & $\geq 10^{5}$ & 81 & 40.3 \\
Suspected & $10^{3}-10^{4}$ & 104 & 51.7 \\
Contaminated & $<10^{3}$ & 13 & 6.5 \\
Negative & Nil & 3 & 1.5 \\
Total & & 201 & 100.0 \\
\hline
\end{tabular}


Table 2. Distribution of asymptomatic bacteriuria by age group among healthy pregnant women

\begin{tabular}{ccc} 
Age group & Total tested (\%) & Number positive (\%) \\
\hline $18-27$ & $154(76.6)$ & $46(29.9)$ \\
$28-37$ & $47(23.4)$ & $35(74.5)$ \\
Total & $201(100.0)$ & $81(40.3)$ \\
\hline
\end{tabular}

Fisher's exact test; $P=0.001$

Table 3. Distribution of asymptomatic bacteriuria by trimester among healthy pregnant women

\begin{tabular}{ccc} 
Trimester & Total tested (\%) & Number positive (\%) \\
\hline $\mathbf{1}^{\text {st }}$ trimester (a) & $61(30.3)$ & $16(26.2)$ \\
$\mathbf{2}^{\text {nd }}$ trimester (b) & $73(36.3)$ & $28(38.4)$ \\
$\mathbf{3}^{\text {rd }}$ trimester (c) & $67(33.3)$ & $37(55.2)$ \\
\hline Total & $201(100.0)$ & $81(40.3)$ \\
\hline
\end{tabular}

Fisher's exact test: $\mathrm{a}$ and $\mathrm{b} ; P=0.3 ; \mathrm{b}$ and $\mathrm{c} ; P=0.23$; $\mathrm{a}$ and $\mathrm{c} ; P=0.03$

Table 4. Profile of Bacteria Isolated from Positive Asymptomatic Bacteriuria

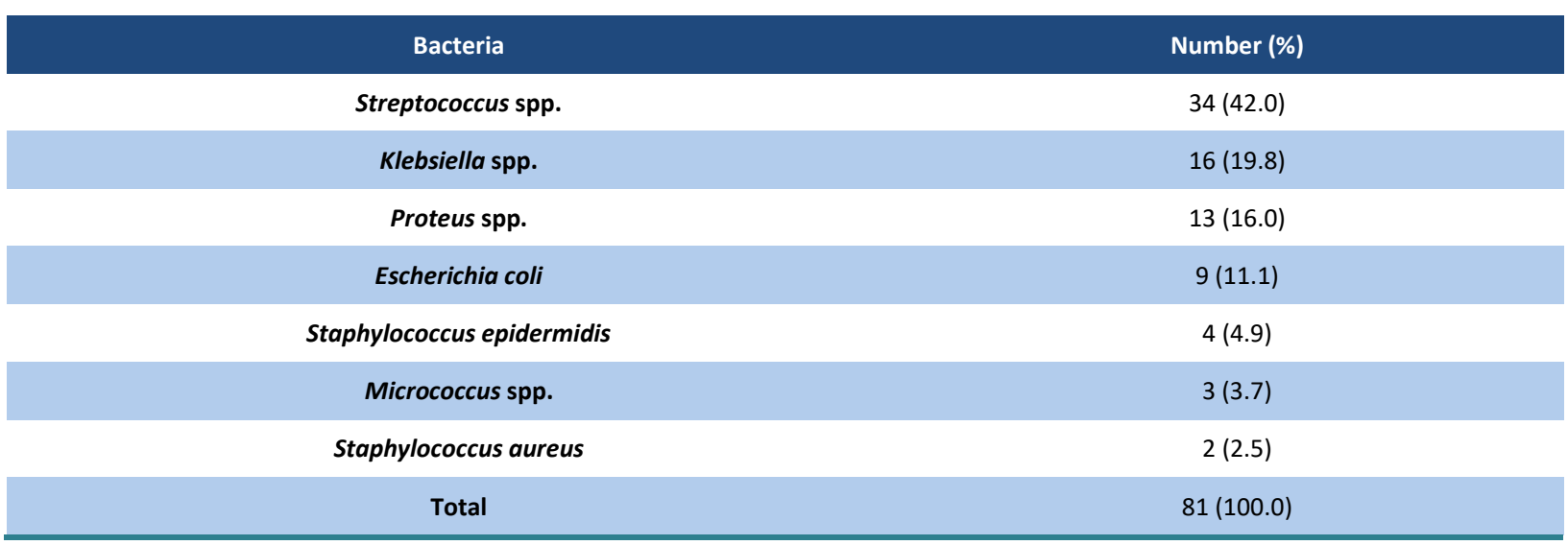

Table 5. Percentage of Bacterial Isolates Susceptible to Nine Antibiotics

\begin{tabular}{|c|c|c|c|c|c|c|c|}
\hline Antibiotics & $\begin{array}{l}\text { Streptococcus } \\
\text { spp. }\end{array}$ & $\begin{array}{l}\text { Klebsiella } \\
\text { spp. }\end{array}$ & $\begin{array}{c}\text { Staphylococcus } \\
\text { epidermidis }\end{array}$ & $\begin{array}{c}\text { Escherichia } \\
\text { coli }\end{array}$ & $\begin{array}{l}\text { Micrococcus } \\
\text { spp. }\end{array}$ & $\begin{array}{c}\text { Staphylococcus } \\
\text { aureus }\end{array}$ & $\begin{array}{c}\text { Proteus } \\
\text { spp. }\end{array}$ \\
\hline E & $29(85.3 \%)$ & $0(0.0 \%)$ & 4 (100.0\%) & 0 (0.0\%) & 1 (33.3\%) & $1(50.0 \%)$ & $0(0.0 \%)$ \\
\hline GEM & 34 (100.0\%) & $6(37.5 \%)$ & $4(100.0 \%)$ & $9(100.0 \%)$ & 3 (100.0\%) & 2 (100.0\%) & $\begin{array}{c}10 \\
(76.9 \%)\end{array}$ \\
\hline AM & 31 (91.1\%) & $2(12.5 \%)$ & 4 (100.0\%) & 9 (100.0\%) & 3 (100.0\%) & $2(100.0 \%)$ & $8(61.5 \%)$ \\
\hline CIP & 34 (100.0\%) & 16 (100.0\%) & $4(100.0 \%)$ & 9 (100.0\%) & $3(100.0 \%)$ & $2(100.0 \%)$ & $\begin{array}{c}13 \\
(100.0 \%)\end{array}$ \\
\hline SP & 32 (94.1\%) & $14(87.5 \%)$ & 4 (100.0\%) & $7(77.8 \%)$ & 3 (100.0\%) & $2(100.0 \%)$ & $9(69.2 \%)$ \\
\hline OFX & 34 (100.0\%) & 16 (100.0\%) & $4(100.0 \%)$ & 9 (100.0\%) & 3 (100.0\%) & 2 (100.0\%) & $\begin{array}{c}12 \\
(92.3 \%)\end{array}$ \\
\hline C & $23(67.7 \%)$ & $0(0.0 \%)$ & $4(100.0 \%)$ & $0(0.0 \%)$ & $1(33.3 \%)$ & $0(0.0 \%)$ & $0(0.0 \%)$ \\
\hline $\mathrm{CHL}$ & 31 (91.1\%) & $2(12.5 \%)$ & $4(100.0 \%)$ & $2(22.2 \%)$ & $2(66.6 \%)$ & $0(0.0 \%)$ & $0(0.0 \%)$ \\
\hline CXM & $29(85.3 \%)$ & $0(0.0 \%)$ & $1(25.0 \%)$ & $0(0.0 \%)$ & $1(33.3 \%)$ & $0(0.0 \%)$ & $0(0.0 \%)$ \\
\hline
\end{tabular}

Key: E- Erythromycin, GEM- Gentamicin, CXM- Cefuroxime, AM- Amoxicillin. CIP- Ciprofloxacin. SP- Sparfloxacin. OFX- Ofloxacin. CCotrimoxazole, $\mathrm{CHL}$ - Chloramphenicol. 


\section{Discussion}

ASB rarely causes serious problems in non-pregnant women. However, in pregnant women, the infection can progress upward causing acute urethritis, cystitis and pyelonephritis $(5,6)$. Furthermore, there is a substantial risk that the infecting pathogens are becoming resistant to empirically prescribed antimicrobial agents normally used in the community.

This study revealed a $40.3 \%$ prevalence of asymptomatic bacteriuria among pregnant women in Ovia North East LGA Edo State (Table 1). This result is comparable to $45.3 \%$ from the study in Benin City, Nigeria (1). This is higher than the $23.9 \%$ from the study in Sagamu, Nigeria (8), $7.3 \%$ reported in Ghana (18), $7 \%$ reported in Ethiopia (18) and $37.1 \%$ reported in Lagos (19). It is lower than the $78.7 \%$ reported in Abakaliki (10), Nigeria. The variation may be explained by the fact that there were differences in environments, social habits of the community, socioeconomic status, and the standard of personal hygiene and education of the pregnant women under these different studies.

In the present study, it was observed that the pregnant women in the age group 28-37 years had a higher percentage of infection of $74.5 \%$ (Table 2 ). This result is comparable to the $53.1 \%$ reported in Benin City (1). Advanced maternal age was reported as a risk factor for asymptomatic bacteriuria in pregnancy (4). Another reason could be because many women within this age bracket are likely to have had many children before the present pregnancy and it has been reported that multiparity is a risk factor for acquiring asymptomatic bacteriuria in pregnancy $(4,20)$.

In this study, most cases of asymptomatic bacteriuria were found during the $3^{\text {rd }}$ trimester (55.2\%) of pregnancy (Table 3). This result correlates with the study of Saeed et al. (21) and Girishbabu et al. (22). This is as a result of pregnant women not going for urine culture in the early stages of pregnancy (1). It is however contrary to the findings in Ghana. Turpin et al. (18) reported a high percentage of asymptomatic bacteriuria in the first and second trimesters of pregnancy and attributed it to pregnant women in those stages reporting at the antenatal clinic for booking during these periods.

Bacterial isolates have been changing from time to time and from place to place. Most studies have shown that $E$. coli was the most prevalent isolate found $(1,23)$. This report differs from what was observed in this study as Streptococcus spp. (42.0\%) was the most prevalent organism (Table 4). The other organisms isolated include Klebsiella spp., Proteus spp., E. coli, Micrococcus spp., S. epidermidis and S. aureus.
The antibiotic sensitivity varies from hospital to hospital and from the community to the community. This is because of the emergence of resistant strains as a result of indiscriminate use of antibiotics. This study revealed that ciprofloxacin was the most efficacious against the urinary isolates (Table 5 ). This is similar to the finding of Mbata (24) who reported that the higher susceptibility of urinary isolates to ciprofloxacin. Ciprofloxacin and ofloxacin are relatively costly in Nigeria and this limits the misuse.

\section{Conclusion}

Prevalence of ASB among pregnant women was $40.3 \%$ and the main organisms found in urine samples were Streptococcus spp., Klebsiella spp., Proteus spp., E. coli, Micrococcus spp., S. epidermidis and S. aureus. The most efficacious antibiotic against the bacterial isolates in this work was ciprofloxacin. From this study, it is therefore expedient to include urine culture and follow-up treatment as part of routine antenatal check-up to prevent complications associated with untreated ASB.

\section{Acknowledgment}

This research received no specific grant from any funding agency in the public, commercial, or not-forprofit sectors.

\section{Conflict of Interest}

The authors reported no conflict of interest.

\section{References}

1. Imade PE, Izekor PE, Eghafona ON, Enabulele EP, Ophori E. Asymptomatic bacteriuria among pregnant women. J Med Sci, 2010. 2: 263 -6.

2. Nicolle LE, Gupta K, Bradley SF, Colgan R, DeMuri GP, Drekonja D, Eckert LO, Geerlings SE, Köves B, Hooton TM, Juthani-Mehta M. Clinical practice guideline for the management of asymptomatic bacteriuria: 2019 update by the Infectious Diseases Society of America. Clin Infect Dis. 2019 May 2;68(10):e83-110. https://doi.org/10.1093/cid/ciy1121 [DOI:10.1093/cid/ciz021] [PMID]

3. Gómez-Ochoa SA, Vega-Vera A. Systematic review and meta-analysis of asymptomatic bacteriuria after renal transplantation: incidence, risk of complications, and treatment outcomes. Transplant Infect Dis. 2020 Feb;22(1):e13221. [DOI:10.1111/tid.13221] [PMID] 
4. Akinloye O, Ogbolu DO, Akinloye OM, Terry Alli OA. Asymptomatic bacteriuria of pregnancy in Ibadan, Nigeria: a re-assessment. Br J Biomed Sci. 2006 Jan 1;63(3):109-12.

5. Samuel O, Victoria O, Ifeanyi O. Prevalence of asymptomatic bacteriuria among the pregnant women receiving antenatal care at Federal Medical Centre Owerri, Nigeria. Universal J Clin Med. 2016;4(1):1-5.

6. Ramos BD, Kanninen $T$, Sisti G, Witkin SS. Microorganisms in the female genital tract during pregnancy: tolerance versus pathogenesis. Am J Reproduct Immunol, 2015 May;73(5):383-9.. [DOI:10.1111/aji.12326] [PMID]

7. Nicole LE, Bradley S, Colgan R. Infectious diseases society of America guidelines for diagnosis and treatment of asymptomatic bacteriuria in adults. J Infect Dis, 2005 Mar 1:643-54. [DOI:10.1086/427507] [PMID]

8. Olusanya $O$, Ogunledun A, Fakoya TA. Asymptomatic significant bacteriuria among pregnant and non-pregnant women in Sagam, Nigeria. Centr Afr J Med. 1992 Jul 1;38(7):297-302.

9. Akerele, P. Abhulimen, F. Okonofua J. Prevalence of asymptomatic bacteriuria among pregnant women in Benin City, Nigeria. J Obstet Gynaecol. 2001 Jan 1;21(2):141-4. [DOI:10.1080/01443610020026038] [PMID]

10. Amadi ES, Enemou OB, Nwosu OK, Onyeagba RA, Ugbogu OC. Asymptomatic bacteriuria among pregnant women in Abakaliki, Ebonyi State, Nigeria. J Med Sci, 2007, 7: 698 - 700. [DOI:10.3923/ims.2007.698.700]

11. Alfred AO, Chiedozie I, Martin DU. Pattern of asymptomatic bacteriuria among pregnant women attending an antenatal clinic at a private health facility in Benin, South-South Nigeria. Annals Afr med. 2013 Jul 1;12(3):160. [DOI:10.4103/15963519.117625] [PMID]

12. Nicolle LE. Screening for asymptomatic bacteriuria in pregnancy. Canadian Guide on preventive health care. 2003:100-6..

13. Public Health England. Preparation of samples and dilutions, plating and sub-culture. Microbiology
Services Food Water and Environmental Microbiology Standard Method FNES26, vol F2, London: Public Health England. 2014, 35 pp.

14. Caputo S, Ciardo A. Asymptomatic bacteriuria in pregnancy. Clin Terminol. 2001, 152: 315 -8.

15. Chesbrough M. District laboratory practice in tropical countries. Part 2. Cambridge: Cambridge University Press. 2000, 105 -14.

16. CLSI Performance standards for antimicrobial susceptibility testing. Clinical Lab Standards Institute, 2016.

17. Turpin CA, Minkah B, Danso KA, Frimpong EH. Asymptomatic bacteriuria in pregnant women attending antenatal clinic at Komfo Anokye Teaching Hospital, Kumasi Ghana. Ghana M J, 2007, 41: 26 - 9.

18. Gabre-Selassie, S. Asymptomatic bacteriuria in pregnancy, epidemiological clinical and microbial approach. Ethiopia Med J, 1998, 36: 185 -92.

19. Olaniyan JA, Akinleye OM, Folorunso JB, Ipaye TO, Abdulraheem L, Dolapo A, Abosede F. Asymptomatic bacteriuria among pregnant women attending private hospital in Lagos, Nigeria. J Appl Med Sci, 2001, 2: 3076 -80.

20. Fatima N, Ishrat S. Frequency and risk factors of asymptomatic bacteriuria during pregnancy. J Coll Physic, 2006, 16: 273-5.

21. Saeed S, Tariq P. Symptomatic and asymptomatic urinary tract infections during pregnancy. Int J Microbiol Res, 2011, 2: 101 -4.

22. Girishbabu RJ, Srikrishna R, Ramesh ST. Asymptomatic bacteriuria in pregnancy. Int J Biomed Res, 2011 2: 740 - 2.

23. Chandel R, Kanga A, Thakur K, Mokta KK, Sood A, Chauhan S. Prevalence of pregnancy associated asymptomatic bacteriuria: J ObsetGynaecol Ind, 2012, 62: 511 - 4. [DOI:10.1007/s13224-011-00712] [PMID]

24. Mbata TL. Prevalence and antibiogram of urinary tract among prison inmates in Nigeria. Internet J Microbiol, 2007, 3: 344 -9. [DOI:10.5580/557] 